\title{
Uji Aktivitas Antijamur Ekstrak Etanol Umbi Bawang Dayak (Eleutherine americana (Aubl.) Merr. Ex K. Heyne.) terhadap Trichophyton mentagrophytes secara In Vitro
}

\author{
Woris Christoper $^{1}$, Diana Natalia ${ }^{2}$, Sari Rahmayanti ${ }^{3}$
}

\begin{abstract}
Abstrak
Dermatofitosis adalah suatu infeksi pada jaringan berkeratin yang disebabkan karena adanya kolonisasi dari jamur jenis dermatofita. Salah satu spesies dermatofita yang paling banyak menginfeksi yaitu Trichophyton mentagrophytes. Tanaman bawang dayak (Eleutherine americana (Aubl.) Merr. Ex K. Heyne) merupakan tanaman yang biasa digunakan masyarakat untuk mengobati penyakit kulit. Tujuan penelitian ini adalah mengetahui aktivitas antijamur ekstrak etanol umbi bawang terhadap pertumbuhan Trichophyton mentagrophytes, mengetahui kandungan metabolit sekunder dan untuk mengetahui konsentrasi efektif larutan uji yang dapat menghambat pertumbuhan Trichophyton mentagrophytes. Metodologi penelitian ini merupakan eksperimental murni secara in-vitro dengan rancangan acak lengkap posttest only control group design. Aktivitas antijamur ekstrak diuji dengan metode difusi cakram Kirby-Bauer. Kontrol positif yang digunakan adalah itrakonazol $8 \mu \mathrm{g}$ dan kontrol negatif adalah Tween $8010 \%$. Hasil penelitian adalah ekstrak etanol umbi bawang dayak memiliki aktivitas antijamur pada konsentrasi 600; 300; $150 \mathrm{mg} / \mathrm{mL}$, KHM pada $150 \mathrm{mg} / \mathrm{mL}$ dengan zona hambat $9,15 \mathrm{~mm}$, hasil skrining fitokimia didapatkan fenol, flavonoid, tanin, saponin, dan kuinon. Simpulan studi ini ialah ekstrak etanol umbi bawang dayak memiliki aktivitas antijamur terhadap Trichophyton mentagrophytes
\end{abstract}

Kata kunci: antijamur, ekstrak etanol umbi bawang dayak, Trichophyton mentagrophytes

\begin{abstract}
Dermatophytoses are an infection on keratinized cell cause by dermatophytes. Dermatophyte that often infected was Trichophyton mentagrophytes. One of the plants that was usually used as medicine by the society were Eleutherine americana. The objective of this study was to determine the antifungals activity of ethanol extract of Eleuthrine americana bulbus against Trichophyton mentagrophytes in vitro, the secondary metabolite compounds , and the minimum inhibitory concentration (MIC). This study is an in vitro laboratory experimental study with complete randomized design and post-test only control group design. The antifungal activity was determined in the extracts using Kirby-Bauer Disc Diffusion methods against Trichophyton mentagrophytes. Itraconazole $8 \mu \mathrm{g} / \mathrm{disc}$ was used as positive control while Tween 80 10\% ad aquadest was used as negative control. Based on the study result, ethanolic extract of Eleutherine americana bulbus has an antifungal activity at concentration of 600; 300; $150 ; \mathrm{mg} / \mathrm{mL}, \mathrm{MIC}$ at $150 \mathrm{mg} / \mathrm{mL}$ with zone of inhibition $9,15 \mathrm{~mm}$, phytochemical screening test, contains phenol, flavonoid, tannin, saponin, and quinone. The conclusion is Ethanolic extract of Eleutherine americana bulbus has an antifungal activity against Trichophyton mentagrophytes.
\end{abstract}

Keywords: antifungal, ethanolic extract of Eleuthrine americana bulbus, Trichophyton mentagrophytes

Affiliasi penulis: $1 . \quad$ Program Studi Pendidikan Dokter, FK Untan (Fakultas Kedokteran Universitas Tanjungpura). 2. Departemen Parasitologi FK Untan. 3. Departemen Mikrobiologi FK Untan.
Korespondensi: Woris Christoper,Email : Worizzz@gmail.com Telp: 085750169088 


\section{PENDAHULUAN}

Jamur (fungi) adalah mikroorganisme yang termasuk golongan eukariotik dan tidak termasuk golongan tumbuhan. ${ }^{1}$ Jamur dapat menyebabkan terjadinya infeksi pada manusia. Salah satu infeksi akibat jamur dengan insidensi tertinggi yaitu dermatofitosis. $^{2}$ Dermatofitosis adalah suatu infeksi pada jaringan berkeratin (rambut, kulit, dan kuku) yang disebabkan karena adanya kolonisasi dari jamur jenis dermatofita. Infeksi akibat jamur dermatofita dapat ditemukan di seluruh dunia, diperkirakan 20$25 \%$ dari populasi dunia telah terinfeksi oleh jamur dermatofita. Salah satu spesies dermatofita yang paling banyak menginfeksi yaitu Trichophyton mentagrophytes. ${ }^{2}$

Dermatofitosis akibat Trichophyton mentagrophytes dapat ditangani dengan pemberian obat antijamur baik melalui jalur sistemik maupun topikal. Penggunaan obat antijamur tersebut memiliki beberapa efek samping yang tidak diinginkan., Oleh sebab itu perlu dicari agen pengobatan yang baru dengan aktivitas antijamur yang lebih baik dengan toksisitas, serta efek samping yang lebih minimal. ${ }^{4}$ Salah satu implementasi pengobatan alternatif sekarang ini adalah penggunaan tumbuh-tumbuhan sebagai obat herbal. ${ }^{5}$

Bawang dayak (Eleutherine americana (Aubl.) Merr. ex K. Heyne) merupakan salah satu jenis tumbuhan yang memiliki potensi sebagai obat herbal. $^{6,7,8}$ Secara empiris umbi bawang dayak digunakan untuk mengatasi bisul. Umbi bawang dayak memiliki kandungan senyawa aktif yaitu naftokuinon, eleutherin, eleutherol dan isoeleutherine. Naftokuinon yang terkandung dalam umbi bawang dayak merupakan golongan kuinon yang memiliki efek sebagai antimikroba, antijamur, antiviral, dan antiparasit. ${ }^{9}$ Ekstrak etanol dari umbi bawang dayak dilaporkan memiliki kemampuan dalam menghambat pertumbuhan Staphylococcus aureus dan Trichophyton rubrum, sehingga ekstrak etanol umbi bawang dayak juga diduga memiliki aktivitas dalam menghambat pertumbuhan Trichophyton mentagrophytes. ${ }^{10}$ Oleh sebab itu perlu dilakukan penelitian mengenai aktivitas antijamur dari ekstrak etanol umbi bawang dayak terhadap jamur Trichophyton mentagrophytes.

\section{METODE}

Penelitian telah dilakukan di Laboraturium Mikrobiologi Fakultas Kedokteran Universitas Tanjungpura dari Agustus sampai Oktober 2014. Studi ini bersifat eksperimental dengan desain postest only control group design. Variabel bebas adalah ekstrak etanol umbi bawang dayak (Eleutherine americana (Aubl.) Merr. ex K. Heyne) dengan berbagai konsentrasi yaitu 3,75\%, 7,5\%, 15\%, 30\% dan $60 \%$ dan variabel terpengaruh adalah jamur Trichophyton mentagrophytes. Data hasil penelitian diolah dengan uji Anova satu arah dengan derajat kepercayaan 95\% $(=0,05)$, bila didapat perbedaan nyata antar perlakuan maka akan dilanjutkan dengan uji korelasi Pearson untuk menentukan korelasi antara peningkatan konsentrasi ekstrak dan diameter zona hambat yang terbentuk.

\section{HASIL}

Aktivitas antijamur ekstrak etanol umbi bawang dayak dapat diamati melalui diameter zona hambat yang terbentuk pada media uji yang telah diletakkan dengan kertas cakram. Hasil pengamatan uji aktivitas antijamur ekstrak etanol umbi bawang dayak terhadap Trichophyton mentagrophytes setelah diinkubasi selama 5 hari pada suhu $25^{\circ} \mathrm{C}$ pada Tabel 1 .

Tabel 1. Hasil uji aktivitas antijamur ekstrak etanol umbi bawang dayak (Eleutherine americana (Aubl.) Merr. ex K. Heyne) terhadap pertumbuhan Trichophyton mentagrophytes

\begin{tabular}{|c|c|c|c|c|c|}
\hline \multirow{2}{*}{$\begin{array}{c}\text { Konsen- } \\
\text { trasi }\end{array}$} & \multicolumn{5}{|c|}{ Diameter Zona Hambat (mm) } \\
\hline & I & II & III & IV & Rerata \\
\hline \multirow[t]{2}{*}{$60 \%$} & 23,35 & 29,48 & 27,75 & 26,23 & 26,70 \\
\hline & & & & & $\pm 1,31$ \\
\hline \multirow[t]{2}{*}{$30 \%$} & 14,75 & 10,45 & 10,58 & 12,83 & 12,15 \\
\hline & & & & & $\pm 1,02$ \\
\hline \multirow[t]{2}{*}{$15 \%$} & 12,28 & 8,65 & 9,50 & 8,58 & 9,75 \\
\hline & & & & & $\pm 0,87$ \\
\hline $7,5 \%$ & 0 & 0 & 0 & 0 & 0 \\
\hline $3,75 \%$ & 0 & 0 & 0 & 0 & 0 \\
\hline \multirow[t]{2}{*}{ Kontrol + } & 11,85 & 11,55 & 14,70 & 12,15 & 12,56 \\
\hline & & & & & $\pm 0,72$ \\
\hline Kontrol - & 0 & 0 & 0 & 0 & 0 \\
\hline
\end{tabular}


Hasil skrining fitokimia pada ekstrak etanol umbi bawang dayak mengandung senyawa metabolit sekunder yaitu fenol, flavonoid, tanin, saponin, dan kuinon. Hasil skrining fitokimia pada ekstrak etanol umbi bawang dayak dapat dilihat pada Tabel 2 .

Tabel 2. Hasil skrining fitokimia ekstrak etanol umbi bawang dayak (Eleutherine americana (Aubl.) Merr. ex K. Heyne)

\begin{tabular}{lllc}
\hline & \multicolumn{1}{c}{ Pemeriksaan } & \multicolumn{1}{c}{ Pereaksi } & Hasil \\
\hline 1. & Fenol & $\mathrm{FeCl}_{3} 1 \%$ & + \\
2. Flavonoid & $\mathrm{Mg}+\mathrm{HCl}$ pekat & + \\
3. Tanin & $\mathrm{FeCl}_{3} 5 \%$ & + \\
4. Saponin & Aquades & + \\
5. Alkaloid & $\mathrm{HCl} 2 \mathrm{~N}$ & \\
& & ditambahkan: & - \\
& & Pereaksi Meyer & - \\
& & Pereaksi & - \\
& & Dragendorf & \\
& & Pereaksi & \\
& & $\mathrm{Wagner}^{2}$ & \\
6. Kuinon & $\mathrm{NaOH} \mathrm{15 \%}$ & + \\
7. Steroid/Triterpenoid & $\mathrm{CH}_{3} \mathrm{COOH}$ & - \\
& & glasial $+\mathrm{H}_{2} \mathrm{SO}_{4}$ & \\
& & pekat & \\
\hline
\end{tabular}

\section{PEMBAHASAN}

Uji aktivitas antijamur pada penelitian ini telah dilakukan dengan menggunakan metode cakram kertas Kirby-Bauer. Metode ini dilakukan dengan cara merendam kertas cakram pada ekstrak yang akan diujikan ke Medium agar saboraud dekstrosa untuk kemudian diinkubasi pada suhu $25^{\circ} \mathrm{C}$ selama 5 hari. Kemudian diamati zona bening di sekitar kertas cakram.Apabila terdapat zona bening di sekitar kertas cakram, hal itu menunjukkan adanya penghambatan pada pertumbuhan jamur yang disebut sebagai zona hambat.

Uji Aktivitas antijamur dilakukan melalui beberapa tahapan yaitu; peremajaan jamur uji, pembuatan suspensi jamur uji, pembuatan variasi konsentrasi ekstrak etanol umbi bawang dayak dan persiapan kontrol negatif dan positif.

Itrakonazol $8 \mu \mathrm{g} /$ disk digunakan sebagai kontrol positif karena merupakan antijamur yang sensitif terhadap jamur golongan dermatofita. Kontrol negatif yang digunakan dalam penelitian adalah persentase Tween ad aquadest. Konsentrasi kontrol negatif disesuaikan dengan yang digunakan pada pembuatan konsentrasi larutan uji.Kontrol positif yang digunakan adalah itrakonazol $8 \mu \mathrm{g} / \mathrm{disk}$. Tween digunakan sebagai kontrol negatif karena tween digunakan untuk melarutkan ekstrak dalam pembuatan larutan uji yang digunakan untuk pengujian aktivitas antijamur ekstrak etanol umbi bawang dayak, oleh karena itu harus bersifat negatif dan tidak memberikan aktivitas antijamur.

Hasil uji aktivitas antijamur menunjukkan kontrol negatif tidak memiliki aktivitas sebagai antijamur yang ditunjukkan dengan tidak adanya zona hambat di sekitar cakram. Kontrol positif itrakonazol memberikan hasil rerata diameter zona hambat 12,56 $\mathrm{mm}$, zona hambat tersebut dikategorikan sensitif apabila dosis obat ditingkatkan. Obat ini dikatakan sensitif apabila memilki zona hambat $\geq 16 \mathrm{~mm}$; sensitif apabila dosis ditingkatkan 10-15 mm; dan resisten $<9$ $\mathrm{mm}$. Uji aktivitas antijamur dilakukan dengan variasi konsentrasi larutan uji600; 300; 150; 75; 37,5 mg/mL, dari konsentrasi tersebut didapatkan adanya zona hambat pada konsentrasi $600 ; 300 ; 150 ; \mathrm{mg} / \mathrm{mL}$. Berdasarkan hasil pengamatan uji aktivitas antijamur dari ekstrak etanolumbi bawang dayak terhadap pertumbuhan Trichophyton mentagrophytes diperoleh nilai reratadiameter zona hambat yang berkisar antara $9,75-26,70 \mathrm{~mm}$. Hal ini sejalan dengan penelitian yang dilakukan pada jamur uji lainnya yang menyatakan bahwa ekstrak etanol umbi bawang dayak dapat menghambat pertumbuhan jamur Trichophyton rubrumpada konsentrasi $150 \mathrm{mg} / \mathrm{mL}$ dengan diameter zona hambat sebesar 15,06 $\mathrm{mm}^{11}$

Hasil analisis Post-Hoc menunjukkan terdapatnya perbedaaan bermakna antara konsentrasi $600 \mathrm{mg} / \mathrm{ml}$ dengan konsentrasi; 300; 150; mg/ml hal tersebut dikarenakan nilai signifikansinya $<0,05$. Perbedaan besarnya daerah hambatan untuk masingmasing konsentrasi dapat diakibatkan antara lain perbedaan besar kecilnya konsentrasi atau sedikitnya kandungan zat aktif antimikroba yang terkandung di dalam ekstrak, kecepatan difusi bahan antimikroba ke 
dalam medium, kepekaan pertumbuhan bakteri/jamur, reaksi antara bahan aktif dengan medium dan temperatur inkubasi, pH lingkungan, komponen media, waktu inkubasi dan aktivitas metabolik mikroorganisme. ${ }^{11}$ Diameter zona hambat yang menunjukkan peningkatan seiring dengan semakin meningkatnya konsentrasi ekstrak yang diberikan. Pada hasil analisis Pearson didapatkan nilai sebesar 0,897 terhadap uji korelasi yang dilakukan antara peningkatan konsentrasi ekstrak dan diameter zona hambat yang terbentuk. Kekuatan korelasi lebih dari 0,7 - 1 memiliki interpretasi bahwa hubungan antar variabel tersebut sangat kuat. ${ }^{11}$ Peningkatan zona hambat ini dapat terjadi karena semakin tinggi konsentrasi suatu obat maka akan semakin banyak molekul obat yang dapat menduduki reseptor tempat kerja obat sehingga respon yang dihasilkan suatu obat juga akan terus meningkat hingga semua reseptor obat telah diduduki. ${ }^{4}$ Konsentrasi terkecil yang masih dapat menghambat pertumbuhan Trichophyton mentagrophytes yaitu $150 \mathrm{mg} / \mathrm{mL}$ dengan rerata diameter zona hambat yang terbentuk $9,15 \mathrm{~mm}$.

Aktivitas antijamur diduga disebabkan adanya efek sinergisme dari setiap metabolit sekunder yang terkandung dalam ekstrak etanol umbi bawang dayak. Metabolit sekunder tersebut adalah fenol, flavonoid, tanin, saponin, dan kuinon yang memiliki potensi sebagai senyawa antijamur. ${ }^{13,14}$ Senyawa golongan fenolik seperti fenol, flavonoid dan tanin, menghasilkan efek antijamur dengan cara menggangu permeabilitas membran, menghambat pembentukan di dinding sel dan mengganggu aktivitas dari mitokondria sel jamur. ${ }^{15-19}$ Senyawa flavonoid memiliki mekanisme antijamur dengan mengganggu homeostasis mitokondria dan juga dengan mengganggu integritas membran sel jamur. ${ }^{18,19}$ Sedangkan senyawa fenol efek antijamurnya dikarenakan dapat membuat terhentinya siklus sell pada jamur yaitu pada fase replikasi, hal ini dapat mengakibatkan terganggunya proses pembelahan sel yang akan menghambat pertumbuhan dari sel jamur. ${ }^{20}$ Fenol mempunyai efek antijamur dengan cara menyebabkan kerusakan pada mitokondria yang akan menyebabkan penimbunan ROS,mekanisme antijamur lain dari fenol adalah bekerja dengan menghambat sintesis kitin yang penting untuk pembentukan dinding sel. ${ }^{19}$ Tanin memiliki aktivitas antijamur dengan cara menghambat sintesis kitin yang digunakan untuk pembentukan dinding sel pada jamur dan merusak membran sel sehingga pertumbuhan jamur terhambat. Saponin yang termasuk dalam senyawa golongan terpen, memiliki mekanisme kerja seperti deterjen. Setelah berikatan dengan kolesterol senyawa lipofilik dari saponin akan berikatan dengan bagian lipofilik dari membran sel yang akan mengakibatkan rusaknya struktur fosfolipid dari membran sel. Naftokuinon yang merupakan senyawa golongan kuinon diduga merupakan kompenen antijamur utama dalam ektrak etanol umbi bawang dayak. Senyawa golongan naftokuinon telah dilaporkan memiliki efek antijamur terhadap beberapa jamur seperti Trichophyton rubrum dan Candida albicans. ${ }^{10,14}$ Mekanisme kerja dari naftokuinon adalah dengan cara mengganggu permeabilitas membran dari sel jamur, permeabiltas yang terganggu ini mengakibatkan terjadinya kebocoran ion $\mathrm{K}^{+}$dari dalam sel jamur dan juga mengakibatkan terjadinya kebocoran pada substansia intraseluler yang penting bagi pertumbuhan sel jamur. $^{14}$

\section{SIMPULAN}

Konsentrasi Ekstrak etanol umbi bawang dayak yang menghasilkan zona hambat paling besar adalah konsentrasi $60 \%$ namun pada konsentrasi $15 \%$ sudah merupakan konsentrasi yang efektif dalam menghambat pertumbuhan Trichophyton mentagrophytes

\section{SARAN}

Perlu dilakukan penelitian lanjutan untuk mengetahui apakah senyawa naftokuinon yang diisolasi (tunggal) memiliki kemampuan lebih baik sebagai antijamur dibandingkan dengan bentuk sediaan ekstrak dengan aktivitas senyawa yang saling bersinergi.

Perlu dilakukan penelitian lanjutan dengan menggunakan hewan coba untuk melihat toksisitas dan efek farmakodinamik dari ekstrak etanol umbi bawang dayak. 


\section{DAFTAR PUSTAKA}

1. Sutanto I, Suhariah I, Pudji KS, dan Saleha S. Parasitologi kedokteran. Edisi ke-4. Jakarta: Balai Penerbit FKUI; 2008.

2. Brutel GF, dan Morse JS. Mikrobiologi kedokteran Jawetz, Melnick, \& Adelberg (terjemahan). Edisi ke-23. Jakarta: Buku Kedokteran EGC, 2008.

3. Barros MEDS, Santos DDA, Hamdan JS. Evaluation of susceptibility of Trichophyton mentagrophytes and Trichophyton rubrum clinical isolates to antifungal drugs using a modified CLSI microdilution method (M38-A). J Med Microbiol. 2007; 56:514-18.

4. Rang HP, Dale MM, Ritter JM, Moore PK. Pharmacology. Edisi ke-7. London: Churchill Livingstone; 2011.

5. Rivera JO, Loya AM, Ceballos R. Use of herbal medicine and implications for conventional drug theraphy medical sciences. Altern Integ Med. 2013; 2:130.

6. Ifesan ВОт, Hamtasin C, Mahabusar W, Voravuthikunchai SP. Inhibitory effect of Eleutherine Americana Merr. Extract on Staphylococcus aureusisolated from food. JFS. 2009;74:1.

7. Chansukh K, Charoensup R, Palanuvej C, Ruangrungsi N. Antimicrobial activities of selected thai medicinal plants bearing quinonoids. Res $\mathrm{J}$ Pharm Biol Chem Sci. 2014;5:425.

8. Limsuwan S, Voravuthikunchai SP. Boesenbergia pandurata (Roxb.) Schltr. Eleutherine Americana Merr. and Rhodomyrtus tomentosa (Aiton) Hassk. as antibiofilm producing and antiquorum sensing in Streptococcus pyogenes. Thailand: Prince of Songkla University; 2008.

9. Kuntorini EM, dan Nugroho HL. Structural development and bioactive content of red bulb plant (Eleutherine americana); a traditional medicines for local Kalimantan people. Biodiversitas. 2010;11:102-6.

10. Puspadewi R, Adirestuti $P$, Menawati R. Khasiat umbi bawang dayak (Eleuthrine palmifolia (L.) Merr.) sebagai herbal antimikroba kulit. KJIF. 2013; $1: 31-7$.
11. Santoso S. Aplikasi spss pada statistik parametrik. Jakarta: Elex Media Komputindo.2012.

12. Freiesleben $\mathrm{SH}$, Jäger AK. Correlation between plant secondary metabolites and their antifungal mechanisms-a review. Med Aromat Plants. 2014; 3:154.

13. Ferreira MdPSBC, Cardoso MFdc, da Silva FdC, Ferreira VF, Lima ES, Souza JVB. Antifungal activity of synthetic naphthoquinones against dermatophytes and opportunistic fungi: preliminary mechanism of action tests. Ann Clin Microbiol Antimicrob. 2014;13:26.

14. Tian J, Huang B, Luo $X$, Zeng $H$, Ban $X$. The control of Aspergillus flavus with Cinnamomum jensenianumHand.-Mazz essential oil and its potential use as a food preservative. Food Chemistry. 2012; 130: 520-27.

15. Tian J, Ban $X$, Zeng $H$, He J, Chen $Y$. The mechanism of antifungal action of essential oil from dill (Anethum graveolens I.) on Aspergillus flavus. PLoS One. 2012;7:e30147.

16. Pinto E, Vale-Silva L, Cavaleiro C, Salgueiro L. Antifungal activity of the clove essential oil from Syzygium aromaticum on Candida, Aspergillus and dermatophyte species. J Med Microbiol.2009;58: 1454-62.

17. Wu XZ, Cheng $A X$, Sun LM, Sun SJ, Lou HX. Plagiochin E, an antifungal bis (bibenzyl), exerts its antifungal activity through mitochondrial dysfunction induced reactive oxygen species accumulation in Candida albicans. Biochim Biophys Acta. 2009;1790:770-7.

18. Kang K, Fong WP, Tsang PW. Antifungal activity of baicalein against Candida krusei does not involve apoptosis. Mycopathologia. 2010;170: 391-6.

19. Wu XZ, Cheng AX, Sun LM, Lou HX. Effect of Plagiochin E, an antifungal macrocyclic bis (bibenzyl), on cell wall chitin synthesis in Candida albicans. Acta Pharmacol Sin. 2008;29:1478-1485.

20. Ashour ML,Wink M. Genus bupleurum: a review of its phytochemistry, pharmacology and modes of action. J Pharma Pharmacol. 2011;63:305-321 